\title{
The psychology of climate anxiety
}

\author{
Joseph Dodds ${ }^{1, *}$ (1)
}

BJPsych Bulletin (2021) 45, 222-226, doi:10.1192/bjb.2021.18

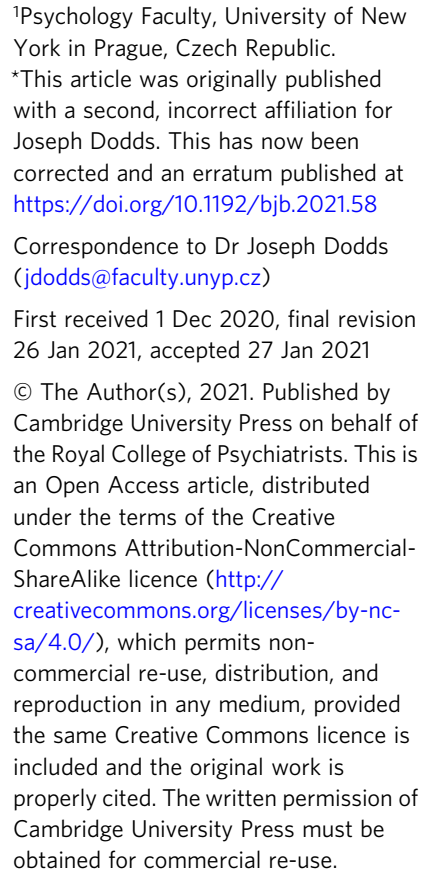

1Psychology Faculty, University of New York in Prague, Czech Republic. *This article was originally published with a second, incorrect affiliation for Joseph Dodds. This has now been corrected and an erratum published at https://doi.org/10.1192/bjb.2021.58

Correspondence to Dr Joseph Dodds (jdodds@faculty.unyp.cz)

First received 1 Dec 2020, final revision 26 Jan 2021, accepted 27 Jan 2021

(c) The Author(s), 2021. Published by Cambridge University Press on behalf of the Royal College of Psychiatrists. This is an Open Access article, distributed under the terms of the Creative Commons Attribution-NonCommercialShareAlike licence (http:// creativecommons.org/licenses/by-nc$\mathrm{sa} / 4.0 /$ ), which permits noncommercial re-use, distribution, and reproduction in any medium, provided the same Creative Commons licence is included and the original work is properly cited. The written permission of Cambridge University Press must be obtained for commercial re-use.

This paper focuses on climate anxiety and its role in the psychology of climate change, compared with responses to the COVID-19 global pandemic. Four psychological hypotheses for why we do not act on climate change will be reviewed, and the role of anxiety for each, as well as potential solutions. Different types of climate anxiety both inside and outside the clinic will be explored, along with associated defence mechanisms and treatment.

Keywords Climate anxiety; climate change; psychoanalysis; post-traumatic stress disorder; ecological trauma.

\section{Climate psychology and climate anxiety}

The past decade has seen the important development of climate psychology. ${ }^{1-7}$ Ursano and colleagues ${ }^{2}$ describe climate change as one of the top threats to global health in the 21st century, and psychology has begun to respond. The American Psychological Association's 2010 report into climate change ${ }^{1}$ identified six key areas for psychology, including risk perception, psychological and behavioural causes of climate change, psychosocial impacts of climate change, adaptation and coping strategies, psychosocial barriers to action and the role of psychologists. At the same time, psychotherapists and clinical psychologists are coming to terms with ecological loss, anxiety and guilt in their patients, and also among themselves, as they come to grips with the faltering biosphere. 8,9

Focuses on climate anxiety and its role in climate psychology, while recognising that anxiety interacts with a range of other emotions such as grief and rage. The American Psychological Association ${ }^{10}$ refers to ecoanxiety as 'a chronic fear of environmental doom', ranging from mild stress to clinical disorders like depression, anxiety, post-traumatic stress disorder and suicide, ${ }^{11-13}$ and maladaptive coping strategies such as intimate partner violence ${ }^{14,15}$ and substance misuse. ${ }^{16-20}$ Cianconi et $\mathrm{al}^{21}$ found complex types of climate anxiety and trauma, including intergenerational effects, especially where environmental damage involves loss of a way of life or culture.
It is essential to differentiate between pathological and adaptive forms. ${ }^{22}$ The Handbook of Climate Psychology ${ }^{4}$ defines climate anxiety as a heightened emotional, mental or somatic distress in response to dangerous changes in the climate system', but suggests that 'paying heed to what is happening. . .is a healthier response than turning away in denial or disavowal'. Climate anxiety can lead to symptoms such as panic attacks, loss of appetite, irritability, weakness and sleeplessness, ${ }^{1}$ yet given the increasing evidence about the impact of climate change on health, psychological professionals might ask if their patients feel too much anxiety, or whether they themselves feel too little. Climate anxiety is being felt much more powerfully among the young, ${ }^{23,24}$ by first responders to climate-related natural disasters $^{25,26}$ and climate scientists and activists, who are exposed to information about the threat more than most and therefore may need psychological support.

When considering the effects of climate anxiety, it is necessary to focus on at-risk populations, including children, the elderly, the chronically ill, those with mental illnesses and those with mobility impairments. ${ }^{2}$ Those from lower socioeconomic groups are disproportionately affected by climate change because of disparities in infrastructure and health resources. Severe weather events can also damage social support systems and mental health infrastructure, further isolating the most vulnerable. ${ }^{27-29}$ Clayon $^{30,31}$ reports that anxiety, fatalism, hopelessness and fear have been 
increasing globally, and offers a clinical approach to understanding, measuring and treating climate anxiety, while emphasising the distinction between adaptive and maladaptive types, and the need to keep the society-level response required to combat climate change in mind.

Given our need to effectively mobilise in response to climate change, the Climate Psychology Alliance ${ }^{4}$ suggests that psychologists and psychotherapists should not aim to get rid of climate anxiety, but instead 'support individuals and communities to build strong containers that allow the expression and exploration of their emotions without collapsing under it or turning away'. Climate change is a psychological problem but that does not mean that it should be individualised or medicalised. As Lawton writes, ${ }^{32}$ if ecoanxiety is treated as pathology, 'the forces of denial will have won...what we are witnessing isn't a tsunami of mental illness, but a longoverdue outbreak of sanity'.

\section{Why do we not act? Four psychological hypotheses}

Climate anxiety is heightened in those that are aware of and feel the existential threat of climate change, by the fact that most of us, most of the time, act as if it does not exist. The poverty of collective responses to climate change is in stark contrast to its threat. Why do we not act? This section explores four psychological hypotheses, the role of anxiety for each, and comparisons with psychosocial responses to COVID-19. ${ }^{33}$

\section{Faulty alarm hypothesis: cognitive bias in our evolved risk detection system}

This explanation suggests humans have evolved the ability to respond to certain types of threats optimally, especially those that are immediate, visible, fast (something happens so slowly that it slips our notice), with historical precedent, simple causality, clear and direct personal impacts or caused by an 'enemy' tribe or group., 1,34,35 From this perspective, the problem with climate change is that we do not feel enough anxiety as it slips our notice by missing all of the characteristics above. The answer is to help us feel the anxiety, to motivate us to act, turning up the volume on the threat and our response. The lack of effective risk perception leads to behaviours that worsen climate change. ${ }^{36}$ According to the 2018 American Psychological Association report, 'the perception of risk regarding climate change, belief in the ability to effect change, and the etiology attributed to extreme weather events are important factors impacting the decisions people make regarding climate change related behaviors'.

\section{Comparison with COVID-19}

Both climate change and COVID-19 are environmental crises where human behaviour and psychology are important factors, yet the latter happens much faster, with clearer links between behaviour and consequence, leading to much more dramatic responses. International efforts to respond to COVID-19 may have the unintended benefit of shaking people out of climate lethargy, by showing that the global mobilisation required to confront climate change is possible, and allowing the public to see (and feel) that invisible environmental dangers are very real. ${ }^{33}$ However, as with climate change, with the COVID-19 pandemic we also see huge levels of denial, anger and despair.

\section{Social dilemma: bystander effect}

Social dilemmas (or commons dilemmas) involve conflict between individual and collective self-interest. ${ }^{37}$ For example, it is in every fisherman's interest for other fishermen to adopt quotas on how much fish can be caught every year to ensure fish stocks recover, but simultaneously, each would like to take what they can. Climate change is the ultimate commons dilemma. ${ }^{38}$ How do we escape from this 'rational-disaster' model of human extinction? Games theory $^{39}$ studies such conflicts, most famously with the prisoners' dilemma. Anxiety here refers to not only the 'costs' of the game when played badly, but of predicting the behaviour of others. How can I trust that you will do the right thing? And how can I trust that you trust that I will do the right thing? Research in human and animal behaviour ${ }^{40,41}$ shows cooperative strategies can flourish in a wide range of contexts. The key is to focus on the structure of the game, to allow cooperative behaviour to flourish.

\section{Comparison with COVID-19}

Responses to both involve social dilemmas. When reviewing how successful different countries were/are in tackling the viral pandemic, it seems that a crucial factor was not the wealth of the nation, but its social cohesion and a collectivist versus individualistic orientation. ${ }^{42-44}$ To the extent that the measures were clearly enunciated, seemed fair and received widespread social support, systems of trust were established and each could play their part in the collective effort. Climate change is another order of complexity beyond COVID-19, but important lessons can be learned.

\section{Ecopsychology: the problem of disconnection from nature}

Since the 1990s, ecopsychology has emerged as a particular response within psychology to environmental problems, emphasising a holistic approach, ${ }^{45-48}$ suggesting that our modern lives are so disconnected from nature that we do not care enough to want to protect it, and fail to realise that we are threatened by damage to the natural world. Ecopsychology views disconnection from nature as also central to the current mental health epidemic. ${ }^{18,49}$ Reconnecting to nature is seen as a requirement for mental health that also provides the emotional link that will drive us to act (out of love, not just fear). Ecopsychologists emphasise that the anxiety, guilt, grief and anger we feel concerning collapsing ecosystems, our 'pain for the World', are appropriate and, although difficult, provides the starting point for action and a renewed relation to Earth. ${ }^{50}$

\section{Comparison with COVID-19}

COVID-19 forces us to recognise that the 'split' between ourselves and nature is not real, and shows that our social systems are all too fragile in the face of environmental 
danger. On the other hand, ecopsychology tends to downplay that nature does at times try to kill us, and is not only a beneficial force that nurtures. For some, COVID-19 is a natural response of Earth to human degradation, as Gaia retaliates against a human civilisation getting too close to remaining wild spaces. In a sense, it has partially worked. COVID-19 has arguably done more than any climate treaty to reduce carbon emissions, ${ }^{33}$ perhaps buying us a little more time. Some hope this is a moment for 'waking up', to take stock and give us a chance to change our futures.

\section{Psychoanalysis: climate denial and apathy as a defence against anxiety}

The psychoanalytic model of environmental problems ${ }^{5-7,51,52}$ focuses on the complex way humans deal with anxiety (see also terror management theory ${ }^{53}$ ). In contrast to the faulty alarm hypothesis, the anxiety of climate change is seen as not too little, but too much, defended against through individual and socially structured defences. ${ }^{9,54}$ Defence mechanisms are strategies the ego uses to defend against anxiety, conflict and threats to self-esteem. From this perspective, as with the Faulty Alarm hypothesis , we need to be able to feel the anxiety (and other feelings) produced by climate change. However, merely amplifying messages of fear and guilt can backfire, by strengthening and rigidifying defences. Climate anxiety is therefore, in part, a realistic but painful response to our situation, and difficult to hold onto, especially in a social context of generalised denial.

\section{Comparison with COVID-19}

The psychoanalytic perspective helps explain certain factors the faulty alarm theory cannot account for, in particular, why responses to climate change include a substantial amount of anger and hostility. Climate scientists have been the recipients of death threats and abuse, and negative reactions in the context of COVID-19 are even more pronounced.

\section{Types of climate anxiety and defence}

Melanie Klein ${ }^{55}$ identified two groups of anxieties. Paranoid-schizoid anxiety involves feelings of persecution and fears of annihilation and fragmentation, and is defended against by psychotic defences (denial of reality), projective identification and splitting. Depressive anxieties relate more to loss, guilt and fears of dependency, dealt with by neurotic defences. We can relate these to the findings of affective neuroscience, ${ }^{56}$ which differentiates the FEAR system (involving the amygdala, medial and anterior hypothalamus, and the periaqueductal gray), which generates anxiety in response to external threats; and the PANIC system (centred on the anterior cingulate gyrus, with connections to thalamic, hypothalamic and other nuclei, such as ventral tegmental areas), which generates anxiety in response to the loss of attachment figures.

The psychoanalytic model suggests that the threat of climate change leads to two types of climate anxiety: first, the 'apocalyptic' fears (fears of death, annihilation and extinction); and second, complex feelings around loss, grief, dependency and guilt ${ }^{52,57}$ for losses that have already occurred and those that are to come ('pre-traumatic stress', 'anticipatory mourning', 'solastalgia ${ }^{58,59}$ ). Responses to climate anxiety include proximal defences (pseudo-rational, threat-focused and more conscious), distal defences (functioning unconsciously and taking a symbolic form) and facing difficult feelings and generating adaptive responses. ${ }^{60}$ Anxiety, guilt and loss become more manageable as they become more shared, ${ }^{61}$ and can be reflected upon in a safe space where realistic possibilities for action open up. All major defence mechanisms ${ }^{62}$ are clearly visible in relation to climate change, focused on the two emotional threats: denying the reality of climate change (it does not exist, it is a conspiracy), or denying our losses, dependency or responsibility (nature might die but we will be fine; it is caused by other humans or natural causes, the Chinese or the sun, not me).

There are many shades of variation: not only outright denial, but minimising the threat (it will not be that bad, it will happen in the future, or to other species or countries), by finding scapegoats through projection; intellectualisation (taking courses on climate change without allowing emotional responses or behavioural change); idealising charismatic leaders that support denial, repressing and suppressing awareness; reaction formation (denying the reality or the impulse while simultaneously giving expression to its opposite, e.g. those who burn a tire for Earth day' or participate in 'coal-rolling', becoming environmentally destructive to prove to themselves they either do not believe in climate change or do not care, as an attack against perceived group enemies, and a means of evacuating bad internal states); hopelessness (it is too late anyway); apocalypticism (the end of the world is exciting and allows for fantasies of the 'bad' being punished for their behaviours, and we can start again and better ${ }^{63}$ ); or manic defence behaviours, such as seeking distraction through increasing addictive behaviours and consumption, ${ }^{18,19}$ to avoid thinking about the problem. A certain amount of climate activism is also of a manic reparation type, which can quickly lead to disillusion and burnout if the movement's goals are not quickly met. These are just a few of the responses/defences that climate change evokes, with many reactions comparable with the COVID-19 pandemic.

\section{Working with climate anxiety}

Adams $^{64}$ asserts that treating climate anxiety needs to address the underlying dangers. and therefore requires meaningful collective responses, including 'acknowledging loss collectively and publicly' as 'an important step in facing up to the reality of the Anthropocene and the impossibility of carrying on "as normal". Randall ${ }^{57,59}$ has emphasised the importance of experiencing and articulating difficult emotions, such as loss, grief and fear, in a shared context as a way of developing forms of mutual support. In addition to dealing with anxiety in their clinical practice, therapists can help support the development of social containers to express, contain and mobilise climate anxiety into positive social change. ${ }^{4}$ Ultimately, the results need to be measured in reduced carbon dioxide emissions rather than necessarily reduced expressions of fear. 
By allowing feelings and thoughts we usually avoid to be brought into awareness, we can avoid more pathological unconscious acting-out. Bednarek ${ }^{65}$ agrees that climate anxiety should not be seen 'as a problem to be solved or a condition to be medicated', but rather 'an important encounter with our awareness of our impact on the world'. All of us need to wake up to climate anxiety, including mental health professionals. Those who are most informed about the current danger, such as scientists, journalists, students or activists, often express the most intense fears - an anxiety heightened by feeling isolated in a culture in denial. ${ }^{66,67}$ Instead of pathologizing their anxiety, which only worsens mental health, we can ask 'what support do we collectively need in order not to freeze and anaesthetise ourselves against this context of so much loss?'65

The answer lies not only from work in individual psychotherapy, but in developing strong social networks of supportive relationships, and a living relationship with the natural world. ${ }^{68}$ Community is crucial for collective resilience, as we are seeing in the COVID-19 pandemic. Nature itself can function as one of these containing spaces. ${ }^{8,46,69}$ To conclude, the symptoms of climate anxiety are not necessarily feelings to be got rid of, but lessons to be learned, although only if they can be felt in a safe way, through developing meaningful action and positive social, psychological and ecological change.

\section{About the author}

Joseph Dodds $(\mathrm{PhD})$ is a psychoanalyst (IPA) in private practice with the Czech Psychoanalytical Society, a psychotherapist (UKCP), Chartered Psychologist (BPS) and psychology lecturer with the University of New York in Prague, and the Anglo-American University..

\section{Declaration of interest}

None.

\section{References}

1 American Psychological Association (APA). Psychology and Global Climate Change: Addressing a Multi-faceted Phenomenon and Set of Challenges. APA, 2010

2 Ursano RJ, Morganstein JC, Cooper R. APA Resource Document Resource Document on Mental Health and Climate Change. American Psychiatric Association, 2018 (https://www.psychiatry.org/File\%20Library/ Psychiatrists/Directories/Library-and-Archive/resource_documents/ 2017-Resource-Document-Mental-Health-Climate-Change.pdf).

3 British Psychological Society. Psychology Has an Important Role in Combating Climate Change. British Psychological Society, 2019 (https://www.bps.org.uk/news-and-policy/psychology-has-important-role-combating-climate-change).

4 Climate Psychology Alliance. The Handbook of Climate Psychology. Climate Psychology Alliance, 2020.

5 Dodds J. Psychoanalysis and Ecology at the Edge of Chaos: Complexity Theory, Deleuze|Guattari and Psychoanalysis for a Climate in Crisis. Routledge, 2011.

6 Weintrobe S. Engaging with Climate Change: Psychoanalytic and Interdisciplinary Perspectives. Routledge, 2012.

7 Hoggett P. Climate Psychology: On Indifference to Disaster. Palgrave, 2019.

8 Rust M-J. Towards an Ecotherapy. Confer Books, 2020.
9 Dodds J. Otto fenichel and ecopsychoanalysis in the Anthropocene. Psychoanalytic Perspectives 2019; 16(2): 195-207.

10 American Psychological Association (A)A. Mental Health and our Changing Climate: Impacts, Implications and Guidance. APA, 2017 (https://www.apa.org/news/press/releases/2017/03/mental-healthclimate.pdf).

11 North CS, Kawasaki A, Spitznagel EL, Hong BA. The course of PTSD, major depression, substance abuse, and somatization after a natural disaster. J Nerv Ment Dis 2004; 293(12): 823-9.

12 Kessler RC, Galea S, Gruber MJ, Sampson NA, Ursano RJ, Wessely S. Trends in mental illness and suicidality after Hurricane Katrina. Mol Psychiatry 2008; 13: 374-84.

13 Arnberg FK, Bergh Johannesson K, Michel P-O. Prevalence and duration of PTSD in survivors 6 years after a natural disaster. J Anxiety Disord 2013; 27(3): 347-52.

14 Harville EW, Taylor CA, Tesfai H, Xiong X, Buekens P. Experience of Hurricane Katrina and reported intimate partner violence. J Interpers Violence 2011; 26: 833-45.

15 Fisher S. Violence against women and natural disasters: findings from post-tsunami Sri Lanka. Violence Against Women 2010; 16(8): 902-18.

16 Flory K, Hankin BL, Kloos B, Cheely C, Turecki G. Alcohol and cigarette use and misuse among Hurricane Katrina survivors: psychosocial risk and protective factors. Subst Use Misuse 2009; 44: 1711-24.

17 Rohrbach LA, Grana R, Vernberg E, Sussman S, Sun P. Impact of Hurricane Rita on adolescent substance use. Psychiatry: Interpers Biol Processes 2009; 72: 222-37.

18 Bodnar S. Wasted and bombed: clinical enactments of a changing relationship to the earth. Psychoanal Dial 2008; 18: 484-512.

19 Bigda-Peyton F. When drives are dangerous: drive theory and resource over-consumption. Mod Psychoanal 2004; 29: 251-70.

20 Fullerton CS, McKibben JBA, Reissman DB, Scharf $T$, KowalskiTrakofler KM, Shultz JM, et al. Posttraumatic stress disorder, depression, and alcohol and tobacco use in public health workers after the 2004 Florida hurricanes. Disaster Med Public Health Prep 2013; 7(1): 89-95.

21 Cianconi $P$, Betrò $S$, Janiri L. The impact of climate change on mental health: a systematic descriptive review. Front Psychiatry 2020; 11: 74.

22 Panu P. Anxiety and the ecological crisis: an analysis of eco-anxiety and climate anxiety. Sustainability 2020; 12(19): 7836.

23 Kelly A. Eco-anxiety at University: Student Experiences and Academic Perspectives on Cultivating Healthy Emotional Responses to the Climate Crisis. University of Colorado at Boulder, 2017 (https://digitalcollections.sit.edu/isp_collection/2642/).

24 Schneider-Mayerson M, Leong KL. Eco-reproductive concerns in the age of climate change. Clim Change 2020; 163: 1007-23.

25 Benedek DM, Fullerton C, Ursano RJ. First responders: mental health consequences of natural and human-made disasters for public health and public safety workers. Annu Rev Public Health 2007; 28: 55-68.

26 Alexander DA, Klein S. First responders after disasters: a review of stress reactions, at-risk, vulnerability, and resilience factors. Prehosp Disaster Med 2009; 24: 87-94.

27 Galea S, Tracy M, Norris F, Coffey SF. Financial and social circumstances and the incidence and course of PTSD in Mississippi during the first two years after Hurricane Katrina. J Trauma Stress 2008; 21(4): 357-68.

28 Rhodes J, Chan $C$, Paxson $C$, Rouse CE, Waters $M$, Fussell $E$. The impact of Hurricane Katrina on the mental and physical health of low-income parents in New Orleans. Am J Orthopsychiatry 2010; $80(2): 237-47$

29 Chan CS, Lowe SR, Weber E, Rhodes JE. The contribution of pre- and postdisaster social support to short- and long-term mental health after Hurricanes Katrina: a longitudinal study of low-income survivors. Soc Sci Med 2015; 138(C): 38-43.

30 Clayton S. Climate anxiety: psychological responses to climate change. J Anxiety Disord 2020; 74: 102263.

31 Clayton S, Karazsia BT. Development and validation of a measure of climate change anxiety. J Environ Psychol 2020; 69: 101434. 
32 Lawton G. If We Label Eco-Anxiety as an Illness, Climate Denialists Have Won. New Scientist, 2019 (https://www.newscientist.com/article/mg 24432512-900-if-we-label-eco-anxiety-as-an-illness-climate-denialistshave-won/).

33 Dodds J. Elemental Catastrophe: Ecopsychoanalysis and the Viral Uncanny of COVID-19. Stillpoint Magazine, 2020 (https://stillpointmag.org/ articles/elemental-catastrophe-ecopsychoanalysis-and-the-viral-uncannyof-covid-19/).

34 Gilbert D. Global Warming and Psychology. Harvard Thinks Big, 2010 (https://vimeo.com/10324258)

35 Marshall G. Don't Even Think About It: Why our Brains Are Wired to Ignore Climate Change. Bloomsbury, 2014.

$36 \mathrm{Koh} \mathrm{H}$. Communicating the health effects of climate change. JAMA 2016; 315: 239-40.

37 Foddy M, Smithson M, Schneider S, Hogg M. Resolving Social Dilemmas. Psychology Press, 1999.

38 Rehmeyer J. Game Theory Suggests Current Climate Negotiations Won't Avert Catastrophe. Science News, 2012 (https://www.sciencenews.org/ article/game-theory-suggests-current-climate-negotiations-wont-avertcatastrophe).

39 Gintis H. Game Theory Evolving: A Problem-Centered Introduction to Modeling Strategic Behavior. Princeton University Press, 2000.

40 Dawkins R. The Selfish Gene. Oxford University Press, 1976.

41 Axelrod R. The Evolution of Cooperation. Basic Books, 2006

42 Cammett M, Lieberman E. Building Solidarity: Challenges, Options, and Implications for COVID-19 Responses. Edmond J. Safra Center for Ethics, 2020 (https://ethics.harvard.edu/files/center-for-ethics/files/ safrawhitepaper4c.pdf).

43 Taylor AL, Habibi R, Burci GL, Dagron S, Eccleston-Turner M, Gostin LO, et al. Solidarity in the wake of COVID-19: reimagining the International Health Regulations. Lancet 2020; 396(10244): 82-3.

44 Saad G. How pathogens affect cultural values and religious edicts: exploring COVID-19 via the evolutionary lens. Psychology Today, 2020 (https://www.psychologytoday.com/gb/blog/homo-consumericus/ 202003/how-pathogens-affect-cultural-values-and-religious-edicts).

45 Rust M-J. Climate on the couch: unconscious processes in relation to our environmental crisis. Psychother Polit Int 2008; 6(3): 157-70.

46 Buzzell L, Chalquist C (eds). Ecotherapy: Healing with Nature in Mind. Sierra Club Books, 2009.

47 Frumkin H, Louv R. The Powerful Link between Conserving Land and Preserving Health. Land Trust Alliance Annual Report, 2007 (https:// www.comalconservation.org/uploads/1/2/0/2/120201064/the_power ful_link_between_conserving_land_and_preserving_health_-_frumkin_ and_louv.pdf).

48 Roszak T, Gomes M, Kanner A. Ecopsychology: Restoring the Earth Healing the Mind. Sierra Club Books, 1995.

49 Santostefano $\mathrm{S}$. The sense of self inside and environments outside: how the two grow together and become one in healthy psychological development. Psychoanal Dial 2008; 18: 513-35.

50 Jordan M. Nature and self - an ambivalent attachment? Ecopsychology 2009; 1(1): 26-41.
51 Searles $\mathrm{H}$. Unconscious processes in relation to the environmental crisis. Psychoanal Rev 1972; 59: 361-74.

52 Lertzman R. Environmental Melancholia: Psychoanalytic Dimensions of Engagement. Routledge, 2015.

53 Pyszczynski T, Solomon S, Greenberg J. Thirty years of terror management theory: from genesis to revelation. Adv Exp Soc Psycol 2015; 52 $1-70$.

54 Kaes R. Linking, Alliances, and Shared Space: Groups and the Psychoanalyst. IPA Publications, 2007.

55 Klein M. The Selected Melanie Klein (ed J Mitchell). Free Press, 1987.

56 Panksepp J. Affective Neuroscience: The Foundations of Human and Animal Emotions. Oxford University Press, 2004

57 Randall R. Loss and climate change: the cost of parallel narratives. Ecopsychology 2009; 1: 3.

58 Freud S. On Transience: On the history of the psycho-analytic movement, papers on metapsychology and other works. (1914-1916). In The Standard Edition of the Complete Psychological Works of Sigmund Freud (ed. Strachey J): 303-307. Hogarth Press and the Institute of Psycho-analysis, 1957.

59 Albrecht GA. Solastalgia and the new mourning. In Mourning Nature: Hope at the Heart of Ecological Loss and Grief (eds A Cunsolo, K Landman): 292-315. McGill-Queen's University Press, 2017.

60 Adams, M. Climate Change, Sustainability, and Psychosocial Defence Mechanism: Infographic. ResearchGate, 2018 (https://www.researchgate.net/publication/322701007_Climate_change_sustainability defence_mechanisms).

61 Randall R. A new climate for psychotherapy? Psychother Pol Int 2005; 3(3): 165-79.

62 Freud A. The Ego and the Mechanisms of Defence. Routledge, 1992

63 Hoggett P. Climate change and the apocalyptic imagination. Psychoanal Cult Soc 2011; 16: 261-75.

64 Adams M. Coming Back Down to Earth: Exploring Distress, Loss and Grie in the Anthropocene. Mad in the UK, 2020 (https://www.madintheuk. com/2020/08/distress-loss-grief-in-the-anthropocene/).

65 Bednarek S. Is there a therapy for climate-change anxiety? Ther Today 2019: 30: 36-9.

66 Schmidt A, Ivanova A, Schäfer MS. Media attention for climate change around the world: a comparative analysis of newspaper coverage in 27 countries. Glob Environ Change 2013; 23: 1233-48.

67 Smith N, Joffe H. How the public engages with global warming: a social representations approach. Public Underst Sci 2013; 22: 16-32.

68 Dodds J. Minding the ecological body: neuropsychoanalysis and ecopsychoanalysis. Front Psychol 2013; 4: 125

69 Jordan M, Marshall H. Taking counselling and psychotherapy outside: destruction or enrichment of the therapeutic frame? Eur J Psychother Couns 2010: 12(4): 345-59.

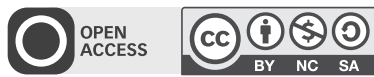

